\title{
Chapter 16 \\ State-Subsidised Refurbishment \\ of Socialist Apartment Buildings \\ in Estonia
}

\author{
Kalle Kuusk and Jarek Kurnitski
}

\begin{abstract}
Apartment buildings in large urban housing estates constitute a large share of the housing supply. Most apartment buildings that are located in housing estates are over 30 years old and, for the most part, only minor refurbishment work has been carried out on them so far. Common problems for these apartment buildings are high energy consumption levels and poor indoor climate conditions. Although research has shown that the condition of load-bearing constructions is satisfactory, some problems do exist which are related to the degradation of facades and balconies. When it comes to restoring these buildings, two different approaches have been discussed in Estonia: demolishing the old buildings and replacing them with brand new apartment buildings; or refurbishing the existing buildings. The vision which prefers the demolition of the old apartment buildings and the construction of new buildings has not been realised in practice thanks to the high costs involved, and also due in part to the apartments being privately owned. The economic and environmental reasons favour an intensive refurbishment of the existing buildings. The costs involved in such an intensive level of refurbishment work are approximately three or four times lower than they would be for putting up a brand new apartment building. From the environmental aspect, rebuilding is also not particularly reasonable thanks to the much higher energy and carbon footprint involved in the use of new building materials. Refurbishment has also generated positive effects on the macroeconomic level, as quantified in terms of job creation and tax returns. In practical terms, refurbishment has been the only feasible solution when it comes to modernising apartment buildings.
\end{abstract}

Keywords Apartment buildings • Refurbishment • Demolition • Energy efficiency

\author{
K. Kuusk $(\square) \cdot$ J. Kurnitski \\ Department of Civil Engineering and Architecture, Nearly Zero Energy Buildings Research \\ Group, Tallinn University of Technology, Tallinn, Estonia \\ e-mail: kale.kuusk@ttu.ee \\ J. Kurnitski \\ e-mail: jarek.kurnitski@ttu.ee \\ (C) The Author(s) 2019 \\ D. B. Hess and T. Tammaru (eds.), Housing Estates in the Baltic Countries, \\ The Urban Book Series, https://doi.org/10.1007/978-3-030-23392-1_16
}




\subsection{Refurbishment Motivators}

There are various approaches to renovating apartment buildings in housing estates. Three main scenarios have been proposed for discussion in Estonia (Terk and Keskpaik 2015):

- Demolition and rebuilding by building groups and a redesign of the common space between the buildings.

- Complete modernisation by building groups via the retention of the current load-bearing structures by following the example shown by east Berlin. Floor planning can be updated and extensions can be added (involving lifts, balconies, sanitary facilities, common areas, etc.).

- Carry out refurbishment work on a building-by-building basis. During such work, windows are replaced and additional thermal insulation is applied to the external walls and the roof, along with an upgrade being carried out on building service systems.

The first two scenarios are both expensive and inconvenient for the apartment inhabitants. Demolition also brings up the subject of economic viability and environmental issues. The experience of the Dutch shows that the transformation of the existing housing stock is a much more environmentally efficient way to achieve the same result that demolition and rebuilding would deliver (Itard and Klunder 2007). In Estonia, where apartments are mainly privately owned, demolition is particularly difficult. The condition of the existing building structures means that demolition is not the optimum solution. The results of research covering the current technical condition of old Estonian housing stock refers to it being in a satisfactory condition in terms of load-bearing constructions (Kalamees et al. 2011a, b). Nevertheless, the agenda of the Tallinn Vision Council contained the proposal to demolish a total of 103 of the oldest prefabricated concrete large-panel apartment buildings on Tallinn's oldest large housing estate, that of Mustamäe (Sarv 2013). The concept was to buy apartments from their owners, demolish the buildings, and build new ones. After that, the previous inhabitants could buy new apartments in new apartment buildings. That vision has not been further developed because it was seen as being highly expensive and, in practice, it would be very difficult to buy apartments from their owners on a one-by-one basis.

Demolition is a plausible solution when a particular area is marked for complete rebuilding. At higher volumes, the construction costs would be lower and a larger macroeconomic impact would also be an important factor, but here further detailed analysis is required. On a single building level, refurbishment work is substantially cheaper than erecting a brand new construction. The number of apartment buildings on housing estates makes refurbishment the more favourable solution due to the enormous construction capacity required for a new build. Therefore, the refurbishment of existing apartment buildings has been the aim of the housing policy in Estonia. In order to promote refurbishment projects, state-subsidised refurbishment 


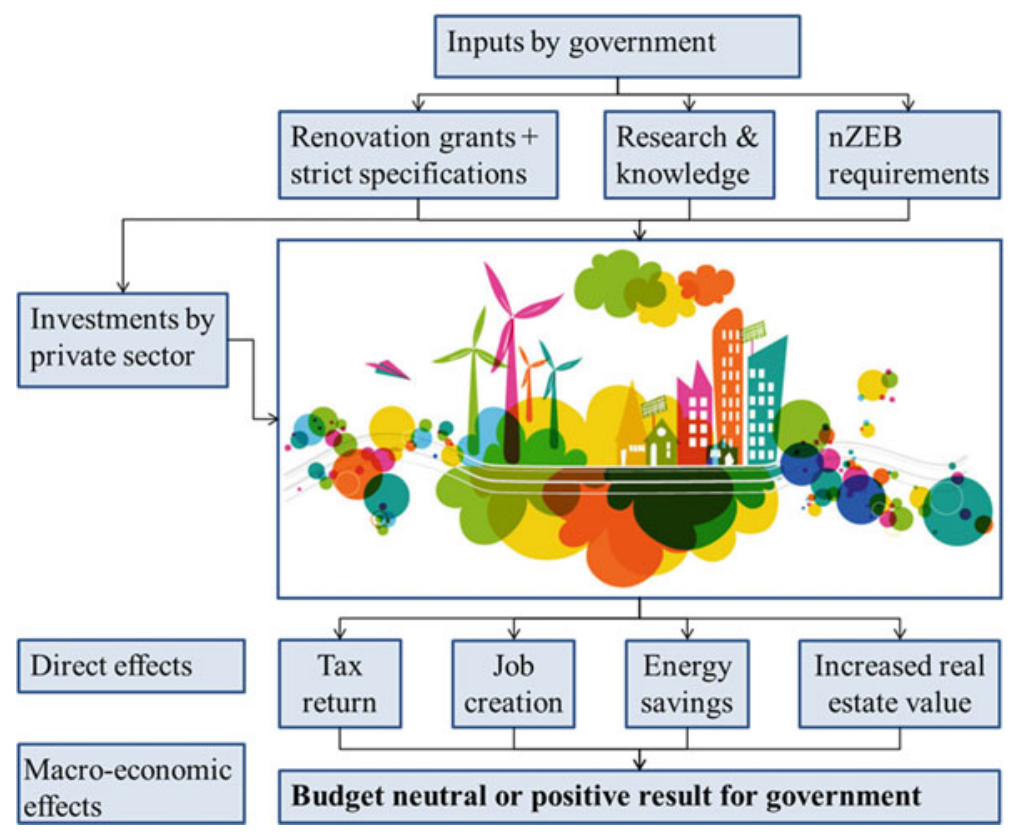

Fig. 16.1 Impacts of renovation plans

programmes have been initiated. The results from grant schemes have shown that state-managed grants have a large number of impacts, as shown in Fig. 16.1.

The main opportunity being provided by a state-managed refurbishment scheme is the ability to be able to guide the refurbishment processes towards the desired direction. The grant scheme allows the creation of energy-efficient building policies through technical research-based requirements for the refurbishment work. The grant scheme also has macroeconomic effects in terms of tax returns and job creation. Another important factor is the mobilisation of private-sector investments. The grant support schemes have, over the years, significantly raised apartment owners' contributions towards energy refurbishment targets. The average investment made by apartment associations has increased by more than double. The increase of private-sector investments is the outcome of the different levels of the extent of refurbishment work. Minor refurbishment work has gradually been replaced by extensive refurbishment work.

\subsection{Estonian Apartment Building Stock}

According to Statistics Estonia, there are 23,600 apartment buildings in Estonia. Most of these apartment buildings were built during the industrialised construction period between 1960-1990, as shown in Fig. 16.2. Large housing estates were the 


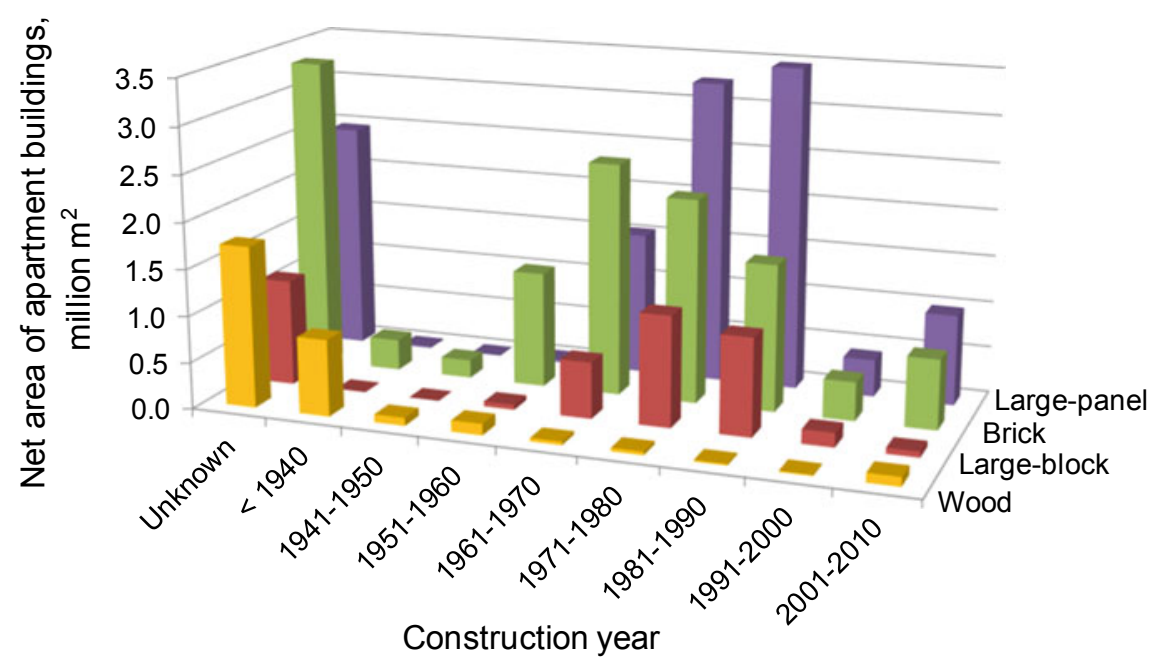

Fig. 16.2 Distribution of apartment buildings in Estonia according to age and construction type

main outcome of the large-scale construction programmes of that era. For example, three main housing estates in Tallinn can be categorised into this way (Table 16.1). Based on the primary construction materials in use, it can be seen that there are four main apartment building types in Estonia: wood; autoclaved, aerated large concrete blocks; brick; and prefabricated, reinforced large concrete panels. The majority of the wooden apartment buildings were built before World War II. After World War II, the construction of wooden apartment buildings decreased significantly and was pretty much finished after the 1960s (Arumägi 2015). Nowadays, those districts which have wooden apartment buildings are being nominated as historically valuable areas. Aerated large concrete block buildings are composed, as may be suggested, of large blocks. These are mainly two- to five-storey buildings, and in architectural terms, they are visually similar to the smaller types of brick apartment buildings. Brick apartment buildings have an inner, load-bearing layer of 250$630 \mathrm{~mm}$ in thickness, $60-120 \mathrm{~mm}$ of low-quality thermal insulation, and a $120 \mathrm{~mm}$ external layer. Both buildings types have been used in smaller towns and villages and also on larger housing estates (Fig. 16.3).

Prefabricated large concrete panel apartment buildings are the most common building type to be used on large housing estates. The panels of the external walls

Table 16.1 Number of apartment buildings in Tallinn housing estates

\begin{tabular}{l|l|l|l|l}
\hline & $\begin{array}{l}1961- \\
1970\end{array}$ & $\begin{array}{l}1971- \\
1980\end{array}$ & $\begin{array}{l}1981- \\
1990\end{array}$ & Total \\
\hline Mustamäe & 246 & 90 & 30 & 366 \\
\hline Õismäe & 6 & 193 & 38 & 237 \\
\hline Lasnamäe & 68 & 123 & 321 & 512 \\
\hline
\end{tabular}



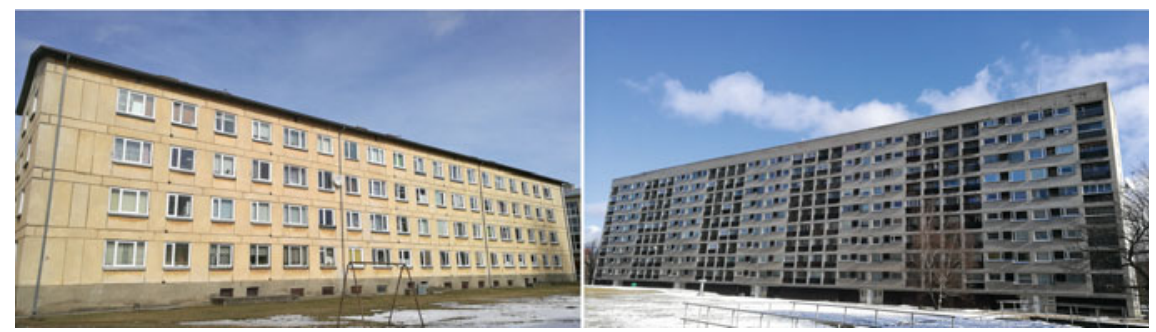

Fig. 16.3 Large block (left) and brick (right) apartment buildings in Tallinn housing estates

are composed of two layers of reinforced concrete (a 50-125 $\mathrm{mm}$ inner layer and a $30-70 \mathrm{~mm}$ outer core) with low-quality thermal insulation of $100-150 \mathrm{~mm}$ in between. Typological series 1-464 apartment buildings in Mustamäe (Fig. 16.4) have five (Type A) or nine (Type D) storeys. A single 1-464 typology building consists of between four and eight sections in a row, each having one staircase. One of the key shortcomings of the five-storey concrete apartment buildings is the absence of lifts. Those buildings which were erected in the Õismäe and Lasnamäe districts were of series 121 . The main difference when comparing them to series 1-464 is the design which focuses on sections instead of an entire building. A building may be composed of several sections that differ from one another. In addition, apartment buildings of series 133 and 66 have been used in various cities around Estonia.

The Estonian housing market is characterised by a high rate of private ownership of housing stock (97\%) and a high rate of owner-occupancy (about $82 \%$ of non-vacant conventional dwellings) (National Report on Estonia, TENLAW). Such an ownership structure is the result of the privatisation process, which in Estonia took place in the 1990s after the collapse of the Soviet Union. During the Soviet Union period, property such as dwelling units in apartment buildings was in public ownership. The private ownership of every apartment makes any large-scale and systematic process of renovating and refurbishing apartment buildings a complicated one. Apartment buildings are generally managed by apartment associations. All apartment owners are members of the apartment association and are responsible

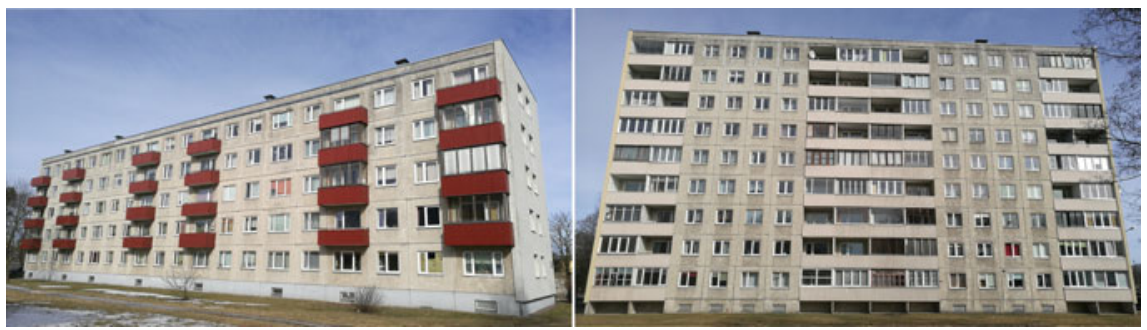

Fig. 16.4 Large-panel apartment buildings in Mustamäe: 1-464A (left) and 1-464D (right) 
for decisions and payments. This means that more than $50 \%$ of apartment owners in each building must agree on the scope of any refurbishment work and also on the budget for any such work.

\subsection{Energy Efficiency and the Current Technical State of Estonian Apartment Building Stock}

Energy efficiency levels in buildings are expressed through primary energy usage. Primary energy takes into account the energy used in buildings (space heating, ventilation, domestic hot water and all electricity loads), and the environmental impact, with weighting factors according to the energy carrier. Residential buildings are divided into eight 'Energy Performance Certificate' (EPC) classes (as shown in Fig. 16.5), in which Class A denotes the highest energy efficiency levels (the nZEB level), and Class $\mathrm{H}$ the lowest level. Existing apartment buildings are usually EPC Class F or G. All modernist apartment buildings from the industrialised construction era have similar thermal transmittance levels. As energy prices were very low at the time, the thermal transmittance of the building envelope was high. The low quality of the construction work and the variations in the materials used and in their parameters were also important factors for the high thermal transmittance of the building envelope. Thermal transmittance values for the external walls of the apartment buildings were as follows:

- prefabricated concrete large-panel wall $\mathrm{U} \approx 0.8-1.2 \mathrm{~W} /\left(\mathrm{m}^{2} \cdot \mathrm{K}\right)$;

- brick wall (without insulation) $\mathrm{U} \approx 1.6-2.0 \mathrm{~W} /\left(\mathrm{m}^{2} \cdot \mathrm{K}\right)$;

- brick wall (with $60 \mathrm{~mm}$ of insulation) $\mathrm{U} \approx 0.8-1.2 \mathrm{~W} /\left(\mathrm{m}^{2} \cdot \mathrm{K}\right)$;

- autoclaved aerated concrete block wall $\mathrm{U} \approx 0.6-0.8 \mathrm{~W} /\left(\mathrm{m}^{2} \cdot \mathrm{K}\right)$.

Building structures at that time contained significant thermal bridges (Ilomets et al. 2017), so the thermal transmittance of the building envelope as a whole is
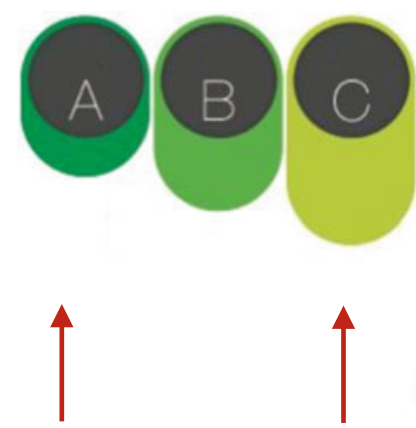

nZEB

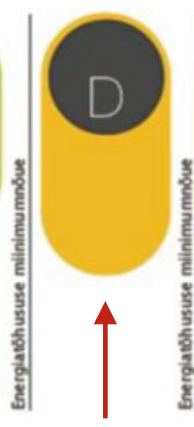

Major renovation

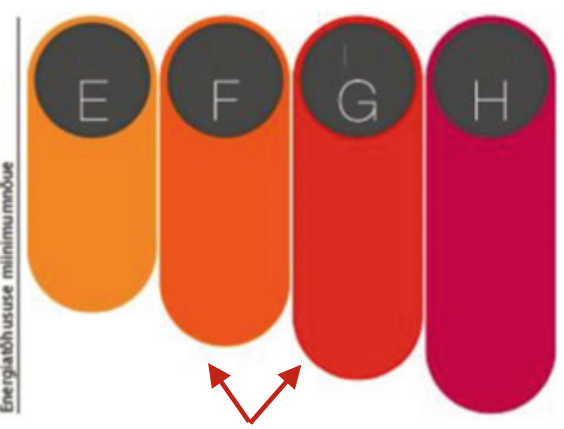

Existing buildings

Fig. 16.5 Energy performance certificate classes for apartment buildings 
actually higher than the thermal transmittance of its single parts. By comparison, the modern recommendation for thermal transmittance in an external wall is $\mathrm{U} \approx 0.15 \mathrm{~W} /\left(\mathrm{m}^{2} \cdot \mathrm{K}\right)$. Approximately, $70 \%$ of flats in Estonia are located in low-energy-efficiency apartment houses (Pittini et al. 2015). The average heating energy consumption level for apartment buildings in Estonia is approximately 140$150 \mathrm{kWh} /\left(\mathrm{m}^{2} \cdot \mathrm{a}\right)$ (Kuusk 2015) which is higher than the average Northern European heating energy consumption level (cf. Balaras et al. 2005; Engvall et al. 2014; Paiho et al. 2015).

Apartment buildings in Estonia are heated mainly by means of district heating and have a one-pipe heating system with hydronic radiators and no thermostats. The indoor temperature is regulated only in heating substations. The ventilation system is natural passive stack ventilation with mechanical kitchen hoods installed by apartment owners. Common problems which are related to building service systems include insufficient ventilation, mould growth due to that insufficient ventilation, uneven indoor temperatures, and insufficient thermal comfort levels.

High energy consumption levels and poor indoor climate are not the only problems when it comes to existing apartment buildings. Research has shown that although the condition of load-bearing constructions is satisfactory, there exist problems which are related to degradation of facades and balconies. Additional external thermal insulation together with the improvement of ventilation is advised in order to eliminate critical thermal bridges and to stop degradation mechanisms (Ilomets 2017). The temperature of the external layer of an old facade after applying external thermal insulation remains above $+10{ }^{\circ} \mathrm{C}$ throughout the year, meaning no more freeze-thaw damage.

\subsection{Refurbishment Grant Schemes in Estonia}

The investment capabilities of apartment associations are not sufficient to be able to cover the cost of crucial repair work and to significantly improve the building's energy efficiency levels. The analysis showed that the apartment owners' capability of being able to invest in energy efficiency is lower than that necessary to meet current energy efficiency requirements. Apartment owners' own funds often allow only for single refurbishment measures and often do not result in any significant change in energy use. Even worse, such repairs have typically neglected ventilation completely and have led to a deterioration of indoor climate with potential adverse health effects upon the occupants. Therefore, financial support is required in order to be able to carry out refurbishment work in apartment buildings in order to achieve future energy efficiency targets and to assure adequate indoor climate conditions. Without grants being made available, the annual cost (in terms of energy costs and refurbishment loan repayments) after any refurbishment work is carried out would be too high for apartment owners to be able to afford, and this would make it difficult for the apartment association to make a decision in favour of major refurbishment work. Subsidies increase the interest of apartment owners in investing in energy efficiency improvements. 
During the 2010-2014 period, a total of 663 apartment buildings underwent refurbishment work in Estonia under the umbrella of a support scheme that was joint-financed by Assigned Amount Unit trading and a government budget, with the administration of the scheme being handled by Fund KredEx (http://kredex.ee/en/). In addition to the refurbishment grant, a refurbishment loan was also made available at a low interest rate and with a long repayment period. The refurbishment loan was financed by European Structural Funds. Total investments from apartment associations and the grant scheme amounted to 151 million euros, of which 38 million euros were grants. Average energy savings for each apartment building were at $43 \%$, and the total annual energy saving was approximately 60 GWh (Lauri 2014).

A total of 102 million euros from the European Union Structural Funds was used in the new grant scheme for 2015-2017. Under the new scheme, technical requirements and the application process were further developed and were more detailed. A $15 \%$ grant can be applied when an Energy Performance Certificate (EPC) of Class E (covering minor refurbishment work) is achieved after the completion of any refurbishment work, while a $25 \%$ grant can be applied when EPC Class D (covering the energy efficiency requirement for major refurbishment work) is achieved after the completion of any refurbishment work, and a $40 \%$ grant can be applied when EPC Class C (covering the energy efficiency requirement for new apartment buildings) is achieved after the completion of any refurbishment work.

In addition to the EPC class, requirements are also in place for thermal transmittance in the building envelope, the heating system, and the ventilation system. A $15 \%$ refurbishment grant does not come with any additional requirements for the building envelope because this grant share is used mainly for minor refurbishment work and improving the indoor climate, areas which may not include the refurbishment of the entire building envelope. Although there are no specific requirements for the building envelope, a heating energy reduction of at least $20 \%$ is required. The main difference between the 25 and $40 \%$ grants is the fact that the $40 \%$ grant also has a requirement for the window and external wall thermal bridge. In order to be able to fulfil these requirements, windows must be moved into the insulation layer. Another option is to insulate the window jamb with an insulation layer that is at least $50 \mathrm{~mm}$ thick, which in practice is often impossible. Fulfilling the thermal transmittance requirements for external walls usually means the creation of an insulation layer that is between 150 and $200 \mathrm{~mm}$ thick. Fulfilling the thermal transmittance requirements for the roof usually means $300-400 \mathrm{~mm}$ of insulation layer. The requirements for windows are only for those windows that are going to be replaced and only for old wooden-framed windows that have not so far been replaced and which certainly do have to be replaced.

The heating system has only two requirements: the system must be balanced and radiators have to be equipped with thermostats in order to allow room-based indoor temperature control.

Ventilation and indoor air quality were the main problems in the previous refurbishment grant scheme (Kõiv et al. 2014). Therefore, special attention was paid to ensure that refurbishment work would include the installation of the ventilation 
system, and that the requirements and the compliance of the ventilation system could be met. Continuous average ventilation (for each apartment in total) should be $0.51 / \mathrm{h}$. Supply or intake air flow rates are required to be at least $101 / \mathrm{s}$ in bedrooms, with living rooms exhibiting sound levels that are no more than $25 \mathrm{~dB}$ (A). Extract air flow rates are required to be at least 101/s in the WC, 151/s in the bathroom and 81/s in the kitchen (or 101/s in the bathroom and 61/s in the kitchen in one room flats). A $40 \%$ grant required that the ventilation system utilise heat recovery. A supply and extract ventilation system with an apartment-based air handling unit and an exhaust ventilation system with an exhaust air heat pump for heat recovery were previously used in standard refurbishment work practices. A new solution in Estonia which evolved from new ventilation requirements involves the central air handling unit with ventilation ducts inside the facade insulation layer, as shown in Fig. 16.6. This solution has become one of the main ventilation solutions in the current refurbishment work grant scheme.

In order to pay more attention to the preparation and commissioning process, the new grants scheme has three main differences when compared to the previous measure. The first innovation is the technical consultant for apartment associations. These individuals have undergone specialist training which focuses on the problems involved in the refurbishment of apartment buildings and the solutions that can be applied. The purpose of technical consultants is to help apartment associations make the right choices and to steer a rather complex refurbishment process that involves a good many parties (such as the board and members of the apartment association, the energy auditor, the designer, the contractor, and the bank). The second innovation is the review process for a developed design by third-party experts in order to ensure that all technical requirements are fulfilled and design documents are prepared to an adequate level of quality. A summary of the review process report is also often required by commercial banks as part of the refurbishment grant process in order that a refurbishment loan may be issued. The third innovation is the commissioning process. A measuring protocol for ventilation airflows must be drawn up in order to confirm that the required ventilation rates are achieved. Results showed that the commissioning of ventilation requirements, and an obligation to present the airflow rate measurement protocol in order to confirm
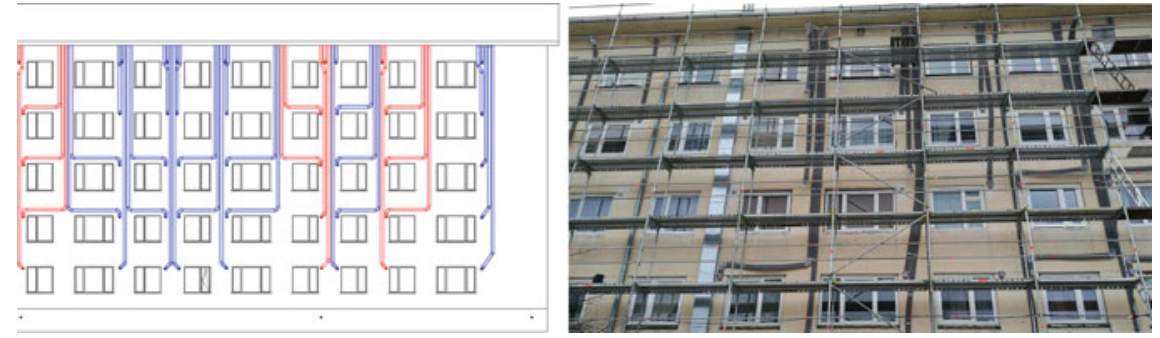

Fig. 16.6 Ventilation ducts in façade insulation layers: schematic view with red supply air ducts and blue exhaust air ducts (left), and photo (right) 

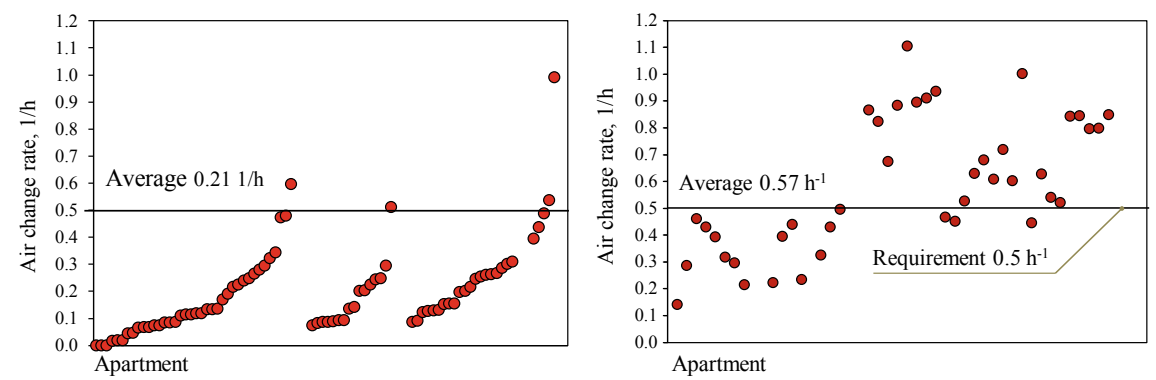

Fig. 16.7 Measured average ventilation air change rates: previous grant scheme (left) and new grant scheme (right)

that the required ventilation rates are achieved, has significantly improved ventilation air change rates in apartment buildings that have already undergone refurbishment work. Average ventilation air change rates which have been measured operationally - as shown in Fig. 16.7—-serve to illustrate the effects of compliance procedures. Under the new grant scheme, even in operational situations in which airflow rates may have been reduced by the inhabitants of apartments, the ventilation system provided values that were close to or higher than $0.51 / \mathrm{h}$.

Although various stakeholders were, at the start of this process, pessimistic when it came to the new technical requirements, the results showed that the grant scheme has worked better than expected. Approximately, $90 \%$ of applications were received for the $40 \%$ grant, which refers to extensive integrated refurbishment work. This shows that with the help of a financial incentive, apartment owners are willing to invest in order to carry out extensive integrated refurbishment work.

\subsection{The Economic Impact Involved in Refurbishment Work on Apartment Buildings - National Economic Impact}

Large-scale refurbishment programmes have a significant impact at the macroeconomical level. Pikas et al. (2015) analysed refurbishment projects in order to discover the tax revenue and job generation for each one million euros of investment. Figure 16.8 summarises the distribution of construction costs. The projects were analysed on the basis of the project budget, while costs were classified into three different categories. On average, $12 \%$ had been spent on project management costs. Labour costs account for $34 \%$ of construction costs, and material costs totalled $54 \%$.

The distribution of project costs was used to calculate job creation and tax revenues for each one million euros of investment (directly) into the construction site and (indirectly) into the consultancy and manufacturing sectors. The average 
Fig. 16.8 Distribution of projects costs

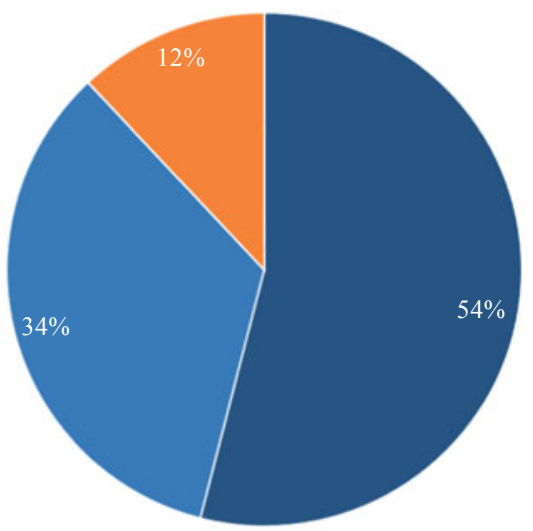

- Material costs, $€ \quad$ - Labor costs for employer, $€$

- Project management costs, $€$

total tax revenue from the refurbishment projects was between 32 and $33 \%$, including VAT and direct and indirect employment taxes (Fig. 16.9). Employment tax revenue included social security tax, unemployment insurance, funded pension contributions and unemployment insurance. The average total tax revenue for each one million euros of investment was $324,000 €$. The average direct tax revenue from construction was $28 \%$, whilst the average indirect tax revenue was $1 \%$ from consultancy and $3 \%$ from manufacturing. Tax revenue from manufacturing only included employment-related taxes, as VAT is paid during the construction phase, making the tax revenue from construction the highest of all of the options. If the objective is to balance tax revenue against government investment then a suitable subsidy for project costs would be between 32 and 33\%, because an average of $28 \%$ from construction and $4 \%$ from manufacturing and consultancy are remitted. In

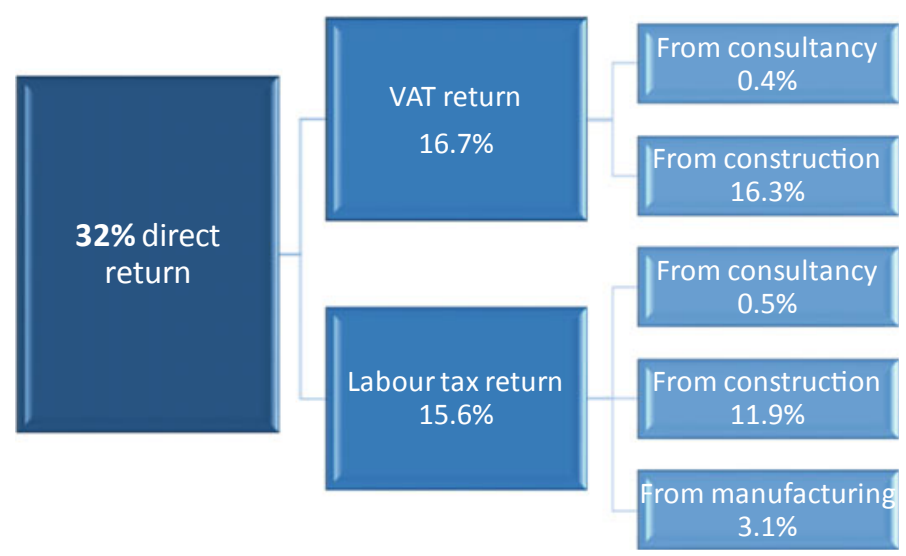

Fig. 16.9 Distribution of tax revenue 
addition to tax revenue, an average of 17 jobs was created for each one million euros of investment.

\subsection{The Impact upon Households of Refurbishment Work}

The main concerns of apartment owners (in Estonia, apartments are occupied mainly by their owners) tends to relate to investment costs and total costs (in terms of loans, maintenance, and energy) after the refurbishment work has been completed. Total cost and energy savings are important factors when a decision is made regarding refurbishment work. An analysis of refurbished apartment buildings showed that the average cost for an intensive refurbishment is approximately $260 € / \mathrm{m}^{2}$. Extensive refurbishment work provides an approximate reduction of $50 \%$ in terms of heating energy. A reduction in heating energy should be even higher but a change in the consumption habits of the inhabitants (in terms of a higher indoor temperature after the refurbishment work has been completed) tends to decrease the energy savings. Electricity consumption increases between 10 and $20 \%$ due to the electricity being used in the newly installed mechanical ventilation system.

A cost analysis for refurbishment work showed heating costs being at $60 €$ / MWh (including VAT), and an electricity price of $113 € / \mathrm{MWh}$ (including VAT), and for the funding of the refurbishment work a loan period of 20 years and an interest rate of $3 \%$. The results of the cost analysis as shown in Fig. 16.10 allows the conclusion to be drawn that, although work for extensive refurbishment requires fairly high initial investment levels, the reduction in heating energy use and the

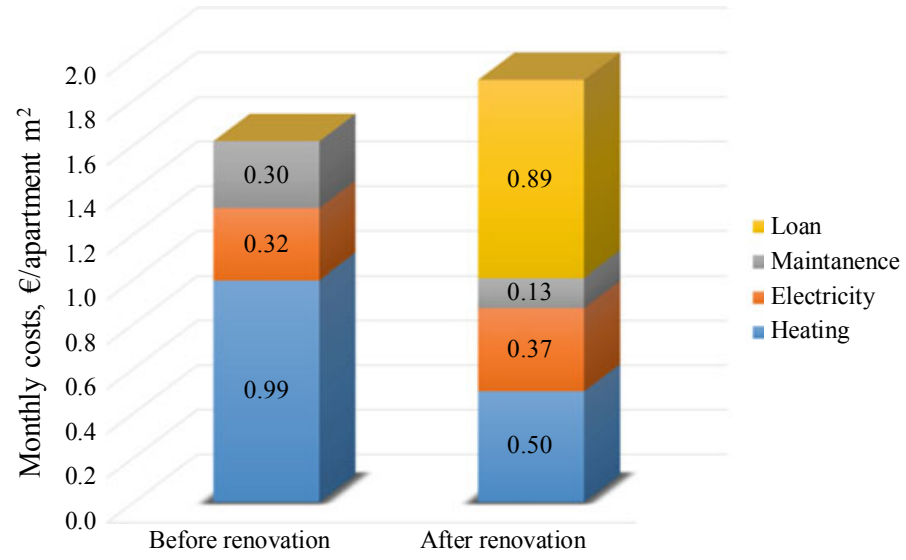

Fig. 16.10 Monthly costs for households before and after renovation (measured for $\mathrm{m}^{2}$ of living space in apartments) 
financial help from the grant scheme will keep the monthly costs for apartment owners at a fairly reasonable level. Monthly average costs together with loan payments are approximately $20 \%$ higher when compared to the situation before the refurbishment scheme had been carried out.

Considering current property values, an analysis of property-related transaction prices for apartments in refurbished apartment buildings when compared to the prices for apartments in non-refurbished apartment buildings in the same area showed that refurbishment work may, albeit not necessarily, increase the value of the property in question (Allekand 2014). As a result of refurbishment work having been carried out, the statistical average value of property increased by $9 \%$.

A survey which was carried out across 40 households in apartment buildings that had already undergone refurbishment work found positive satisfaction results from the occupants (Kalamees et al. 2017), reporting that almost all households were satisfied with the results of the refurbishment work in terms of energy savings, thermal comfort levels, and indoor air quality. A modest increase in monthly payments was highlighted by $30 \%$ of households, but the occupants commented that they could keep room temperatures at between 22 and $23{ }^{\circ} \mathrm{C}$ thanks to well-insulated buildings and relatively small energy bills, which serves to indicate that occupants who are in apartments which have poor thermal quality levels prefer their thermal comfort to be on the warm side. The benefits from refurbishment work, such as a better living environment, better indoor climate and smaller energy bills, were all reported, fully compensating for the slightly increased monthly costs which included loan payments to the bank.

\subsection{Refurbishment Bottlenecks}

The refurbishment of an apartment building usually involves measures that are designed to improve the condition of the building envelope and its service systems. Public spaces between buildings and apartment layouts are not changed. Tallinn Vision Council has pointed out that the floor planning for these old dwellings is unsuitable for families (Sarv 2013) because the bathrooms and kitchens are too small. In addition, in the five-storey buildings, narrow staircases and the absence of lifts restrict the movement of families with small children and elderly or disabled people. Living standards have changed and conditions in apartments on housing estates are no longer considered to provide the best living environment. Lõoke (2016) studied the 1-464 series large-panel apartment building, and proposed four possible solutions for problems that were related to living conditions:

- Major work - to change all of the apartments in the same way and, for the most part, to a considerably major extent. For example, adding a new room to all apartments which are positioned at the end of the apartment building.

- Variable - the layout of the apartments in the 1-464 series is rather rigid, and there are not that many ways in which they can be improved. By building a new 
communications shaft through all of the apartments it is possible to change the layouts, but if this is positioned correctly then it will not considerably change the apartment for anyone who prefers not to have such a change.

- Communal - those operations that do not change the apartments themselves but which add some form of function or amenity to the apartment building which can be used by all of the apartment owners. For example, a sauna on the roof of the building.

- Repartitioning the apartments - there is a lack of apartments in the building stock which have a large number of rooms. In order to correct this, it is possible to merge apartments together, forming larger apartments. Usually merging two apartments together will result in an apartment that is too large, so it's reasonable to merge three apartments together instead of in order to form two larger ones that are still reasonably sized.

Refurbishment work will affect the architectural appearance of the buildings. Housing estates have generally been built as homogenous environments. Taking a building-by-building approach to the refurbishment of apartment buildings has changed that (Fig. 16.11). Every building has its own architectural design and the initial modern homogenous environment is often not followed anymore. Guidance for local the municipality or for a general refurbishment plan for an entire group of buildings would help to prevent that problem.

Although there already exist buildings on housing estates that have undergone refurbishment work, that refurbishment work has been too slow for the desired renewal of housing stock. The current refurbishment rate for apartment buildings in Estonia is approximately $1 \%$ per year ( 200 buildings). Refurbishment schemes have shown that a higher refurbishment rate raises the construction cost due to the

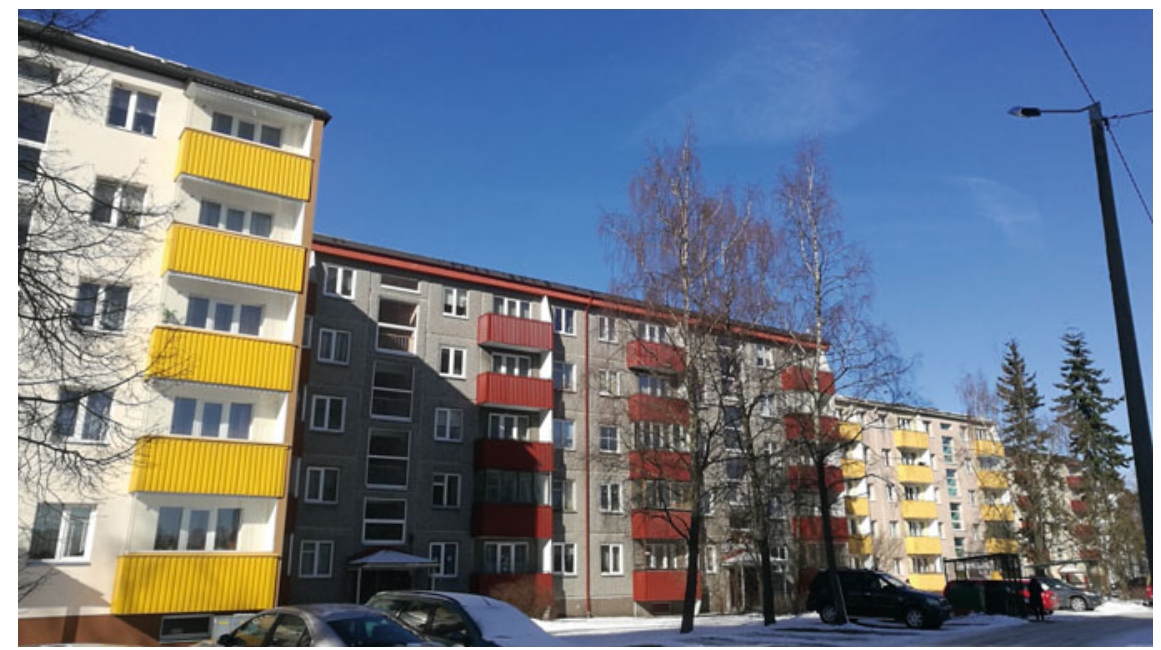

Fig. 16.11 Various façade treatments on adjacent apartment buildings 


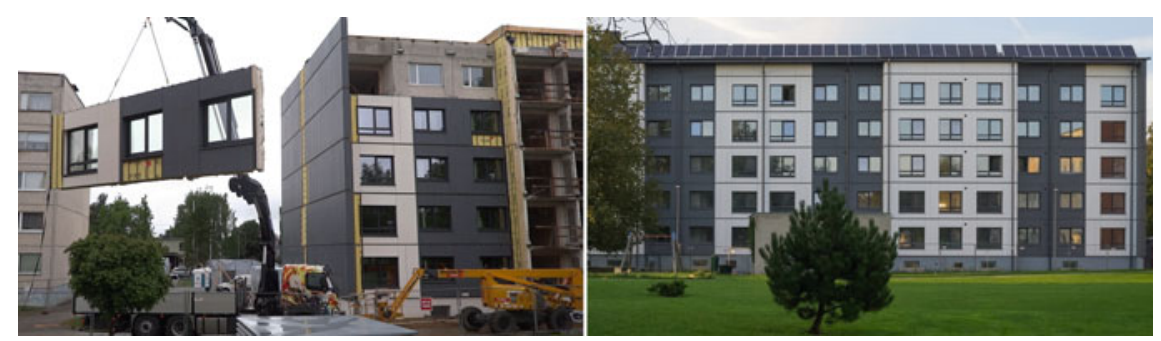

Fig. 16.12 Installation of modular wall panels (left) and the finished building (right)

higher demand for and limited number of construction workers. Current refurbishment work mainly uses labour-intensive refurbishment technologies. Refurbishment work on one apartment building takes approximately 6 months. In order to increase the rate at which refurbishment work takes place, new technologies are needed. One possible solution is to handle refurbishment work using prefabricated modular panels. The concept of using prefabrication in the refurbishment process involves timber frame external wall elements with insulation, a façade cover, and windows all being pre-assembled at the factory. The quality of the work is higher and installation onsite does not require scaffolding. In 2017, a large-panel apartment building, which was used as a dormitory for Tallinn University of Technology, underwent refurbishment work using prefabricated walls and roof modular panels (Fig. 16.12). The prefabrication solution would allow for a significantly shorter time being taken to handle such refurbishment work. The estimated installation time for external wall elements is 2 weeks for one apartment building. So far this building is the only pilot project in Estonia to undergo refurbishment work using prefabricated façade elements.

\subsection{Conclusions}

Apartment buildings in large urban housing estates are essential to ensure a housing supply. There are visions which involve the demolition of old apartment buildings and building new ones. Although this approach would theoretically supply a complete resolution of the problems regarding public space between the buildings and regarding the apartment layouts, the economic and environmental reasons favour the extensive integrated refurbishment of existing buildings. In the case of privately owned and occupied Estonian apartments, refurbishment work with governmental grants seems to be the solution that works. Today around 1,100 existing apartment buildings out of about 20,000 in the total stock have undergone refurbishment work. Energy efficiency increases and an indoor climate condition which is comparable to modern apartment buildings have been achieved following the application of an intensive refurbishment process. At the same time, the cost of 
an intensive refurbishment is approximately three or four times lower than it would be for putting up a new apartment building. From the environmental aspect, rebuilding is also considered as being unreasonable due to the much higher embodied energy and carbon footprint of building materials.

Large-scale refurbishment work has generated positive effects at the macroeconomic level, something which can be quantified in terms of job creation and tax returns. In all, seventeen jobs for each one million euros of investment in refurbishment work had been created both directly and indirectly per year in Estonia. Tax revenue from refurbishment projects has been quantified to be between 32 and $33 \%$. Therefore, evidence from Estonia suggests that a state-subsidised refurbishment programme has, in practical terms, been budget-neutral with direct financial supports of $25-40 \%$ in use during the past 10 years.

Acknowledgements This research was supported by Resource Efficient Smart Buildings and Districts, ZEBE, grant 2014-2020.4.01.15-0016 sponsored by the European Regional Development Fund.

\section{References}

Allekand I (2014) Kortermaja rekonstrueerimine ei pruugi selle väärtust tõsta (in Estonian). https:// domuskinnisvara.ee/2014/10/09/kortermaja-rekonstrueerimine-ei-pruugi-selle-vaartust-tosta/

Arumägi E (2015) The refurbishment of historic wooden apartment buildings. Doctoral thesis, Tallinn University of Technology

Balaras CA, Droutsa K, Dascalaki E, Kontoyiannidis S (2005) Heating energy consumption and resulting environmental impact of European apartment buildings. Energy Build 37:429-442

Engvall K, Lampa E, Levin P, Wickman P, Öfverholm E (2014) Interaction between building design, management, household and individual factors in relation to energy use for space heating in apartment buildings. Energy Build 81:457-465

Ilomets S, Kuusk K, Paap L, Arumägi E, Kalamees T (2017) Impact of linear thermal bridges on thermal transmittance of renovated apartment buildings. Journal of Civil Engineering and Management 23(1):96-104

Ilomets S (2017) Refurbishment need and performance of envelopes of concrete apartment buildings in Estonia. Doctoral thesis, Tallinn University of Technology

Itard L, Klunder G (2007) Comparing environmental impacts of renovated housing stock with new construction. Build Res Inf 35:252-267

Kalamees T, Ilomets S, Arumägi E, Alev Ü, Kõiv T-A, Mikola A, Kuusk K, Maivel M (2011a) Indoor hygrothermal conditions in Estonian old multi-storey brick apartment buildings. In: The 12th international conference on indoor air quality and climate, Indoor Air, Austin, Texas, pp 5-10

Kalamees T, Õiger K, Kõiv T-A, Liias R, Kallavus U, Mikli L, Lehtla A, Kodi G, Arumägi E (2011b) Technical condition of prefabricated concrete large-panel apartment buildings in Estonia. In: International Conference on Durability of Building Materials and Components. Porto, Portugal, pp 973-981

Kalamees T, Hamburg A, Mikola A, Kurnitski J (2017) Rekonstrueeritud korterelamute sisekliima ja energiakasutuse analüüs (in Estonian). http://kredex.ee/public/Uuringud/Rekonstrueeritud_ korterelamute_sisekliima_ja_energiakasutuse_analuus.pdf 
Kõiv T-A, Hamburg A, Mikola A, Kiil M, Tukia A, Rohula T, Siim G, Palmiste Ü (2014) Rekonstrueeritud korterelamute sisekliima ja energiatarbe seire ja analüüs ning nende vastavus standarditele ja energiaaudititele (in Estonian). http://www.kredex.ee/public/Uuringud/ Rekonstrueeritud_korterelamute_uuring.pdf

Kuusk K (2015) Integrated cost-optimal refurbishment of apartment buildings toward nearly zero-energy buildings. Doctoral thesis, Tallinn University of Technology

Lauri M (2014) Korterelamute renoveerimisturu ülevaade ja perioodi 2010-2014 korterelamute rekonstrueerimistoetuse mõju analüüs (in Estonian). http://www.kredex.ee/public/Uuringud/ Korterelamute_analuus_030914.pdf

Lõoke T (2016) Kuidas kaasajastada paneelmaju?. Magistritöö, Eesti Kunstiakadeemia

National Report on Estonia, TEN LAW. http://www.tenlaw.uni-bremen.de/

Paiho S, Pinto Seppä I, Jimenez C (2015) An energetic analysis of a multifunctional facade system for energy efficient retrofitting of residential buildings in cold climates of Finland and Russia. Sustain Cities Soc 15:75-85

Pikas E, Kurnitski J, Liias R, Thalfeldt M (2015) Quantification of economic benefits of refurbishment of apartment buildings as a basis for cost optimal 2030 energy efficiency strategies. Energy Build 86(2015):151-160

Pittini A, Ghekiere L, Dijol J, Kiss I (2015) The state of housing in the EU 2015

Sarv M (2013) Mustamäe maha, püsti uus Mustamäe! Eesti Päevaleht. http://epl.delfi.ee/news/lp/ mustamae-maha-pusti-uusmustamae.d?id=65551478 (in Estonian)

Terk E, Keskpaik A (2015) Tallinn's housing scenarios and the future of districts (Tallinna elamispinnastsenaariumid ja „magamislinnaosade“ tulevik) final report (in Estonian), Tallinn University. http://uuringud.tallinnlv.ee/document.aspx?id=11538

Open Access This chapter is licensed under the terms of the Creative Commons Attribution 4.0 International License (http://creativecommons.org/licenses/by/4.0/), which permits use, sharing, adaptation, distribution and reproduction in any medium or format, as long as you give appropriate credit to the original author(s) and the source, provide a link to the Creative Commons license and indicate if changes were made.

The images or other third party material in this chapter are included in the chapter's Creative Commons license, unless indicated otherwise in a credit line to the material. If material is not included in the chapter's Creative Commons license and your intended use is not permitted by statutory regulation or exceeds the permitted use, you will need to obtain permission directly from the copyright holder.

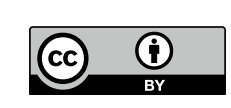

